\title{
The importance of Indigenous Peoples' lands for the conservation of terrestrial vertebrates
}

Christopher J. O’Bryan ${ }^{1,2 *}$, Stephen T. Garnett ${ }^{3}$, John E. Fa ${ }^{4,5}$, Ian Leiper ${ }^{3}$, Jose Rehbein ${ }^{1}$, Álvaro Fernández-Llamazares ${ }^{6}$, Micha V. Jackson ${ }^{2}$, Harry D. Jonas ${ }^{7}$, Eduardo S. Brondizio ${ }^{8}$, Neil D. Burgess ${ }^{9,10}$, Catherine J. Robinson ${ }^{11}$, Kerstin K. Zander ${ }^{12}$, Oscar Venter ${ }^{13}$, James E.M. Watson ${ }^{1,2,14}$

${ }^{1}$ School of Earth and Environmental Sciences, The University of Queensland, Brisbane QLD 4072, Australia

${ }^{2}$ Centre for Biodiversity and Conservation Science, The University of Queensland, Brisbane, QLD 4072, Australia

${ }^{3}$ Research Institute for the Environment and Livelihoods, Charles Darwin University, Darwin, NT 0909, Australia

${ }^{4}$ Division of Biology and Conservation Ecology, School of Science and the Environment, Manchester Metropolitan University, Manchester, UK

${ }^{5}$ Center for International Forestry Research, Situ Gede, Bogor, 16115, Indonesia

${ }^{6}$ Helsinki Instituted of Sustainability Science, University of Helsinki, Helsinki, 00014, Finland

${ }^{7}$ Future Law, Kota Kinabalu 88300, Sabah, Malaysia

${ }^{8}$ Departement of Anthropology, Indiana University Bloomington, Indiana, USA

${ }^{9}$ Center for Macroecology, Evolution and Climate, University of Copenhagen, Copenhagen, DK-2100, Denmark

${ }^{10}$ United Nations Environment Programme World Conservation Monitoring Center (UNEPWCMC), Cambridge, UK

${ }^{11}$ Commonwealth Science \& Industrial Research Organisation (CSIRO), Brisbane, Australia

${ }^{12}$ Northern Institute, Charles Darwin University, Darwin, NT 0909, Australia

${ }^{13}$ Natural Resource and Environmental Studies Institute, University of Northern British Columbia, 3333 University Way, Prince George, V2N 4Z9, Canada

${ }^{14}$ Global Conservation Program, Wildlife Conservation Society, 2300 Southern Boulevard, Bronx, New York, USA

*Corresponding author: Christopher J. O’Bryan: c.obryan@uq.edu.au

Keywords: amphibians, biodiversity conservation, birds, distributions, endangered species, landscape conservation, mammals, sustainable development goals, traditional owners 


\section{Abstract}

2 Indigenous Peoples' lands cover over one-quarter of the Earth's surface, a significant

3 proportion of which is still free from industrial-level human impacts. As a result, Indigenous

4 Peoples' lands are crucial for the long-term persistence of Earth's biodiversity and ecosystem

5 services. Yet, information on species composition within Indigenous Peoples' lands globally

6 remains unknown. Here, we provide the first comprehensive analysis of terrestrial vertebrate

7 composition across mapped Indigenous lands by using distribution range data for 20,328

8 IUCN-assessed mammal, bird and amphibian species. We estimate that 12,521 species (62\%)

9 have $\geq 10 \%$ of their ranges in Indigenous Peoples' lands, and 3,314 species (16\%) have >half

10 of their ranges within these lands. For threatened species assessed, 1,878 (41.5\% of all

11 threatened mammals, birds and amphibians) occur in Indigenous Peoples' lands. We also find

12 that 3,989 species (of which 418 are threatened) have $\geq 10 \%$ of their range in Indigenous

13 Peoples' lands that have low human pressure. Our results are conservative because not all

14 known Indigenous lands are mapped, and this analysis shows how important Indigenous

15 Peoples' lands are for the successful implementation of international conservation and

16 sustainable development agendas. 


\section{$18 \quad 1 . \quad$ INTRODUCTION}

19 Through well-established traditional knowledge systems and governance practices,

20 Indigenous Peoples are the environmental stewards of their lands. This is gradually being

21 recognized in domestic and international policy (Brondizio et al. 2019). A recent analysis

22 indicates that Indigenous Peoples' lands cover at least a quarter of terrestrial Earth,

23 overlapping with $37 \%$ of all terrestrial protected areas and with $40 \%$ of landscapes without

24 industrial-level human impacts (Garnett et al. 2018). Some countrywide assessments

25 demonstrate the importance of Indigenous Peoples' lands in terms of the biodiversity

26 contained within them. In Australia, for example, 45-60\% of the country's threatened species

27 are found in Indigenous Peoples' lands (Renwick et al. 2017; Leiper et al. 2018) and

28 vertebrate biodiversity in Indigenous People's lands in three countries (Australia, Brazil and

29 Canada) are comparable to those found in protected areas (Schuster et al. 2019). However,

30 global assessments of the overlap between Indigenous Peoples' lands and species

31 distributions (including threatened species) are lacking, especially the relationship with areas

32 free from industrial-level human impacts. Such regions are likely to be of high conservation

33 value (Di Marco et al. 2018), given the connection between land use transformation and

34 species declines (Newbold et al. 2015; Maxwell et al. 2016; Tilman et al. 2017). These

35 landscapes may also be important ecological refugia (Scheffers et al. 2016; Allan et al. 2019)

36 offering some protection against the pressures of expanding resource extraction frontiers.

38 Here, we provide the first global assessment of the overlap between mapped Indigenous

39 Peoples' lands (Garnett et al. 2018) and terrestrial vertebrate ranges (IUCN 2016; Birdlife

40 International and Handbook of the Birds of the World 2017). We also assess species

41 composition within Indigenous Peoples' lands with low human pressure using updated

42 'Human Footprint' data (Venter et al. 2016). These results are relevant to the development 
43 and implementation of the post-2020 Global Biodiversity Framework agreement that will

44 emerge from Convention for Biological Diversity's (CBD) target discussions on abating

45 species extinctions and reducing the erosion of ecosystem services (Watson \& Venter 2017;

46 CBD 2018) as well as for nations trying to implement actions to achieve the 2030 United

47 Nation's Sustainable Development Goals.

\section{2. METHODS}

\section{$50 \quad$ Species distribution data}

51 We focused our analysis on the terrestrial vertebrates (mammals, amphibians and birds) that

52 had been comprehensively assessed by the IUCN by 2017. Spatial data on mammal and

53 amphibian distributions were obtained from the IUCN Red List of Threatened Species (IUCN

54 2017), and bird distributions from BirdLife International (Birdlife International and

55 Handbook of the Birds of the World 2017). We excluded species considered Extinct, Data

56 Deficient, or any other extant native and reintroduced species whose distribution did not

57 intersect with the spatial datasets employed in this study.

Spatial data on Indigenous lands

60 Globally, more than 370 million persons in more than 70 countries self-identify as Indigenous

61 Peoples (ILO 2019; see Garnett et al. 2018 for discussion of definitions). We used recently-

62 compiled global spatial data on Indigenous Peoples' lands, sourced or delineated on the basis

63 of open-access published sources (see Garnett et al. 2018 for further details) that, while

64 certainly incomplete, is the best available spatial layer.

65

66 
67 Advances in remote sensing coupled with bottom-up survey data, have enabled the development of a spatially explicit, validated, high-resolution global dataset on human pressures (Venter et al. 2016a). These datasets permit the quantification of the extent of

70 intense pressures on individual species (Di Marco et al. 2018; Allan et al. 2019). We used the

71 most current Human Footprint map available (from 2013), comprising a composite spatial

72 index of key human pressures on natural ecosystems at a $1-\mathrm{km}^{2}$ resolution.

74 Eight human pressure variables were used in the Human Footprint: 1) built environments, 2)

75 population density, 3) electric infrastructure, 4) crop lands, 5) pasture lands, 6) roads, 7)

76 railways, and 8) navigable waterways. These eight individual pressures are scaled between 0

77 and 10 based on their estimated environmental impact and summed in $1 \mathrm{~km}^{2}$ grid cells. Some

78 pressures co-occur whilst others are mutually exclusive, resulting in a combined global scale

79 between 0 and 50 where 0 has no detectable change and 50 is extreme urban conglomerates.

80 We reclassified the Human Footprint map to an index threshold of $<3$ because this threshold

81 is now considered the standard for evaluating the degree of low human pressure across

82 ecosystems (Di Marco et al. 2018; Jones et al. 2018). A threshold of $\sim 3$ is where areas with

83 low states of human pressure transition to human-dominated activities such as pastureland

84 (Venter et al. 2016b). Importantly, index values at or $>3$ reveal an increased extinction risk in 85 mammals (Di Marco et al. 2018).

87 Analysis

88 We combined the spatial datasets on Indigenous Peoples' lands and low-Human Footprint

89 data (not including species data) in a single spatial data layer (in raster format) using a World

90 Molleweide projection in a geographic information system (ESRI ArcGIS) at a $1 \mathrm{~km}^{2}$

91 resolution. To do this, we converted each feature polygon layer into raster format and 
92 reclassified each layer with a layer-explicit value. We summed each raster layer using the

93 raster calculator tool, which resulted in a single raster image containing the values for each

94 layer within each cell. For example, the cells within this single raster image contained

95 information on the presence of Indigenous Peoples' lands (Garnett et al. 2018) and whether

96 the cell contained landscapes with low human footprint (Venter et al. 2016a, 2016b). The

97 layer was then intersected with the ranges of 20,328 terrestrial vertebrates - 4,592 mammal

98 species, 10,743 bird species, and 4,993 amphibian species. We calculated the proportion of

99 land occupied by each species in Indigenous Peoples' lands, in low-pressure landscapes or in

100 both using the tabulate area tool within ArcGIS 10.5 Model Builder (ESRI 2017) and R

101 statistical software (R Core Team 2017). The proportions of all species and threatened

102 species on each land use type were compared using Chi Square with Yates' correction (Yates 103 1934).

\section{RESULTS}

Occurrence of species in Indigenous Peoples' lands

Indigenous Peoples' lands encompass a total of at least 38 million $\mathrm{km}^{2}$ (28.3\%) of terrestrial

Earth (Garnett et al. 2018; Table S1). We find that 12,521 (61.6\%) of all species assessed have at least $10 \%$ of their ranges within these lands, and 3,314 (16.3\%) have $>50 \%$ of their range in these lands (Table 1). Birds have a higher percentage of species with at least $10 \%$ of their ranges in Indigenous People's lands than other classes: $69.6 \%(n=7,481)$ compared to $60.8 \%(\mathrm{n}=2,791)$ of mammals and $45.0 \%(\mathrm{n}=2,249)$ of amphibians. Birds also have the highest mean range proportion containing these lands (25.8\% of range on average) followed by mammals (25.0\%) and amphibians (21.8\%) (Figure 1). However, amphibians have a 
117 Australia and Indonesia have the highest proportion of species with $>50 \%$ of their range within Indigenous Peoples' lands with east Asia, Africa and the mountainous central and

South America also having high proportions (Figure 2).

Of the 4,523 species classified as threatened (i.e. at least Vulnerable on the IUCN Red List), 1,878 (41.5\%) have at least 10\% of their ranges within Indigenous Peoples' lands, with 952 (50.7\%) being Vulnerable, 637 (33.9\%) being Endangered, and 289 (15.4\%) being Critically

124 Endangered on the IUCN Red List. We also find that $840(18.6 \%)$ of all threatened species have $>50 \%$ of their ranges within these lands (Table 2), with 393 (46.8\%) being Vulnerable, $268(31.9 \%)$ Endangered, and 179 (21.3\%) Critically Endangered species. The proportion of threatened species with $>50 \%$ of their range on Indigenous Peoples' lands was higher than for all species ( $\chi^{2}$ with Yates' correction $\left.6.86, \mathrm{P}<0.01\right)$.

We find that threatened amphibians have a slightly higher percentage of species with at least $10 \%$ of their ranges in Indigenous Peoples' lands than other threatened classes: $35.9 \%(\mathrm{n}=$ lands: $24.3 \%(\mathrm{n}=272)$ versus $19.0 \%(\mathrm{n}=389)$ of threatened amphibians and $13.2 \%(\mathrm{n}=$ 179) of threatened birds (Table 2).

\section{Occurance of species in Indigenous Peoples' lands with low human pressure}

138 Nearly 21 million $\mathrm{km}^{2}$ of Indigenous Peoples' lands (15.5\% of all terrestrial Earth, and 45.2\%

139 of all Indigenous Peoples' lands) have low human pressure (Table S1). We find that 3,989

$140(19.6 \%)$ of species assessed have at least $10 \%$ of their range in these low-pressure Indigenous 141 Peoples' lands, with $364(1.8 \%)$ having $>50 \%$ of their ranges in these lands (Table 1). Birds 
142 have a higher percentage of species with at least $10 \%$ of their ranges in Indigenous Peoples'

143 lands with low human pressure than other classes: $22.0 \%(\mathrm{n}=2,360)$ compared to $19.1 \%(\mathrm{n}=$

$144875)$ of mammals and $15.1 \%(\mathrm{n}=754)$ of amphibians. Still, amphibians have a greater

145 percentage of species with $>50 \%$ of their ranges in Indigenous Peoples' lands with low

146 human pressure: $2.4 \%(n=121)$ versus $2.1 \%(n=97)$ of mammals and $1.4 \%(n=146)$ of

147 birds.

149 We find that the percentage of threatened species within low-pressure Indigenous Peoples' lands is considerably lower than that of threatened species across all Indigenous Peoples'

lands (Figure 3). As many as $418(9.2 \%)$ of the threatened species assessed have at least $10 \%$

of their ranges in low-pressure Indigenous Peoples' lands, with 240 (57.4\%) of these being

Vulnerable, 117 (28.0\%) Endangered, and 61 (14.6\%) Critically Endangered species. We also

estimate that $73(1.6 \%)$ of the threatened species assessed have $>50 \%$ of their ranges in these

lands (Table 2), with 48 (65.8\%) of these being Vulnerable, 14 (19.2\%) Critically

Endangered, and $11(15.1 \%)$ Endangered species (Figure 3B). The proportion of threatened

We estimate that threatened mammals have a higher percentage of species with at least $10 \%$

of their ranges in low-pressure Indigenous Peoples' lands than other threatened classes:

$12.3 \%(n=137)$ compared to $9.3 \%(n=126)$ of birds and $7.6 \%(n=155)$ of amphibians 


\section{DISCUSSION}

Indigenous Peoples' lands cover a large portion of Earth's land surface (Garnett et al. 2018), and also include some of the highest quality forest lands worldwide (Fa et al. in press). It follows that Indigenous Peoples are also custodians of a substantial proportion of the world's biodiversity. While it has long been suspected that the proportion of biodiversity in Indigenous Peoples' lands was likely to be high (Toledo 2013), our study is the first to use robust, repeatable methods for determining this. The numbers we have derived are substantial: globally $62 \%$ of mammals, birds and amphibians have $\geq 10 \%$ of their range within Indigenous Peoples' lands; for $16 \%$ of species, including $18 \%$ of threatened species, the proportion is $>50 \%$.

These figures are conservative for a number of reasons. The taxonomic range of the species groups for which we have range data - mammals, birds and amphibians - is but a small fraction of the biodiversity found (Larsen et al. 2017). Our results, based on best available globally consistent species data, is also likely to be true of plants, invertebrates and others forms of biodiversity that could increase the absolute number of species by several orders of magnitude (but see Oberprieler et al. 2019). Moreover, because stringent legislation often controls access to and activities within Indigenous Peoples' lands, affecting the extent to which biodiversity is documented and mapped (dos Santos et al. 2015), it is very likely that survey effort in these lands is still incomplete (e.g., Bernard et al. 2011 for bats in the Amazon). A corollary of this is that Indigenous Peoples could potentially play an important role in filling species knowledge gaps and information deficits in large parts of the planet, as well as in furthering our understanding of the conservation status and population trends of many species, but also levels of species richness, endemism hotspots and largely unknown distribution range discontinuities (Johnson et al. 2015). Indeed, 42.4\% (935 out of 2,203) of 
Data Deficient species from our dataset have $\geq 10 \%$ of their ranges within Indigenous

Peoples' lands. We also note that many of areas not yet mapped as Indigenous Peoples' lands are also likely to retain an Indigenous connection so our numbers are an under-estimate of overall species coverage.

Myriad examples are available on how collaboration between Indigenous Peoples and researchers has refined knowledge of species ecological distribution ranges, baselines and trends (e.g. Mistry \& Berardi 2016; Skroblin et al. 2019). However, such knowledge partnerships need to be negotiated appropriately (Robinson et al. 2016). The central message from this analysis, that Indigenous Peoples' participation, lands and perspectives are vital to any policies and programs aiming to further global biodiversity conservation, strongly aligns with that of the Intergovernmental Science-Policy Platform on Biodiversity and Ecosystem Services (Brondizio et al. 2019; Diaz et al. 2019; IPBES 2019) and many other studies (e.g. Dinerstein et al. 2019; Reyes-García et al. 2019).

Our results point to the fact that Indigenous Peoples' rights must be fully respected, including their full and effective participation in developing laws, policies and programs that affect them. Although representatives of Indigenous Peoples are gradually engaging in global environmental governance, such as IPBES, the Intergovernmental Panel on Climate Change and the $\mathrm{CBD}$, this often occurs in the face of substantial barriers to engagement related to scale, knowledge and power (Brugnach et al. 2017). Greater recognition and support for the relationships that Indigenous Peoples have with their lands and their natural resources is therefore a pressing imperative from the perspective of both social equity and biodiversity conservation (Howitt 2018). Only through equitable partnerships and other forms of collaboration with fully empowered Indigenous Peoples will it be possible to discuss, but 
217 more importantly ensure the long-term conservation of biodiversity on Indigenous Peoples'

218 lands.

\section{Acknowledgments}

221 The work was partially funded by the NASA Biodiversity and Ecological Forecasting

222 Program under the 2016 ECO4CAST solicitation through grant NNX17AG51G. JEF was

223 funded by the US Agency for International Development as part of the Bushmeat Research

224 Initiative of the CGIAR research program on Forests, Trees and Agroforestry.

\section{References}

Allan, J.R., Watson, J.E.M., Di Marco, M., O’Bryan, C.J., Possingham, H.P., Atkinson, S.C. \& Venter, O. (2019). Hotspots of human impact on threatened terrestrial vertebrates. task for two centuries? Mamm. Rev., 41, 23-39. PLOS Biol., 17, e3000158.

Bernard, E., Aguiar, L.M.S. \& Machado, R.B. (2011). Discovering the Brazilian bat fauna: a

Birdlife International and Handbook of the Birds of the World. (2017). Bird species distribution maps of the world [WWW Document]. Version 7.0. URL http://datazone.birdlife.org/species/requestdis

Brondizio, E.S., Settele, J., Diaz, S. \& Ngo, H. (2019). Global assessment report on biodiversity and ecosystem services of the Intergovernmental Science-Policy Platform on Biodiversity and Ecosystem Services. Bonn. $19-32$.

CBD. (2018). Convention on Biological Diversity COP [WWW Document]. URL 
243 Diaz, S., Settele, J., Brondízio, E., Ngo, H., Guèze, M., Agard, J., Arneth, A., Balvanera, P.,

244 Brauman, K., Butchart, S. \& Chan, K. (2019). Summary for policymakers of the global assessment report on biodiversity and ecosystem services of the Intergovernmental Science.

Dinerstein, E., Vynne, C., Sala, E., Joshi, A.R., Fernando, S., Lovejoy, T.E., Mayorga, J.,

Global Deal For Nature: Guiding principles, milestones, and targets. Sci. Adv.

ESRI. (2017). ArcGIS Desktop: Release 10.

Garnett, S.T., Burgess, N.D., Fa, J.E., Fernández-Llamazares, Á., Molnár, Z., Robinson, C.J., Watson, J.E.M., Zander, K.K., Austin, B., Brondizio, E.S., Collier, N.F., Duncan, T., A. \& Leiper, I. (2018). A spatial overview of the global importance of Indigenous lands for conservation. Nat. Sustain., 1, 369-374.

Howitt, R. (2018). Indigenous rights vital to survival. Nat. Sustain.

IPBES. (2019). Global Assessment Report on Biodiversity and Ecosystem Services.

IUCN. (2017). The IUCN Red List of Threatened Species [WWW Document]. Version 20171. URL https://www.iucnredlist.org/

Johnson, N., Alessa, L., Behe, C., Danielsen, F., Gearheard, S., Gofman-Wallingford, V., Kliskey, A., Krümmel, E.-M., Lynch, A., Mustonen, T., Pulsifer, P. \& Svoboda, M. (2015). The Contributions of Community-Based Monitoring and Traditional Knowledge to Arctic Observing Networks: Reflections on the State of the. Source Arct., 68, 28-40.

Jones, K.R., Venter, O., Fuller, R.A., Allan, J.R., Maxwell, S.L., Negret, P.J. \& Watson, J.E.M. (2018). One-third of global protected land is under intense human pressure. Science, 360, 788-791. 
Leiper, I., Zander, K.K., Robinson, C.J., Carwadine, J., Moggridge, B.J. \& Garnett, S.T. (2018). Quantifying current and potential contributions of Australian indigenous peoples to threatened species management. Conserv. Biol., 32, 1038-1047.

Di Marco, M., Venter, O., Possingham, H.P. \& Watson, J.E.M. (2018). Changes in human footprint drive changes in species extinction risk. Nat. Commun., 9, 1-9.

Maxwell, S.L., Fuller, R.A., Brooks, T.M. \& Watson, J.E.M. (2016). Biodiversity: The ravages of guns, nets and bulldozers. Nature, 536, 143-145.

McGowan, P.J.K. (2016). Mapping the terrestrial human footprint. Nature, 537, 172-173.

Mistry, J. \& Berardi, A. (2016). Bridging indigenous and scientific knowledge. Science (80-. )., 352, 1274-1275.

Newbold, T., Hudson, L.N., Hill, S.L.L., Contu, S., Lysenko, I., Senior, R.A., Börger, L., Bennett, D.J., Choimes, A., Collen, B., Day, J., De Palma, A., Díaz, S., EcheverriaLondoño, S., Edgar, M.J., Feldman, A., Garon, M., Harrison, M.L.K., Alhusseini, T., Ingram, D.J., Itescu, Y., Kattge, J., Kemp, V., Kirkpatrick, L., Kleyer, M., Correia, D.L.P., Martin, C.D., Meiri, S., Novosolov, M., Pan, Y., Phillips, H.R.P., Purves, D.W., Robinson, A., Simpson, J., Tuck, S.L., Weiher, E., White, H.J., Ewers, R.M., Mace, G.M., Scharlemann, J.P.W. \& Purvis, A. (2015). Global effects of land use on local terrestrial biodiversity. Nature, 520, 45-50.

Oberprieler, S.K., Andersen, A.N., Gillespie, G.R. \& Einoder, L.D. (2019). Vertebrates are poor umbrellas for invertebrates: cross $\square$ taxon congruence in an Australian tropical savanna. Ecosphere, 10.

R Core Team. (2017). R: A language and environment for statistical computing.

Renwick, A.R., Robinson, C.J., Garnett, S.T., Leiper, I., Possingham, H.P. \& Carwardine, J. (2017). Mapping Indigenous land management for threatened species conservation: An Australian case-study. PLoS One, 12. 
293 Reyes-García, V., Fernández-Llamazares, Á., McElwee, P., Molnár, Z., Öllerer, K., Wilson,

294 S.J. \& Brondizio, E.S. (2019). The contributions of Indigenous Peoples and local

295 communities to ecological restoration. Restor. Ecol.

296 Robinson, C.J., James, G. \& Whitehead, P.J. (2016). Negotiating Indigenous benefits from payment for ecosystem service (PES) schemes. Glob. Environ. Chang., 38, 21-29.

dos Santos, J.G., Malhado, A.C.M., Ladle, R.J., Correia, R.A. \& Costa, M.H. (2015).

Geographic trends and information deficits in Amazonian conservation research.

Biodivers. Conserv., 24, 2853-2863. (80-. ).

Schuster, R., Germain, R.R., Bennett, J.R., Reo, N.J. \& Arcese, P. (2019). Vertebrate biodiversity on indigenous-managed lands in Australia, Brazil, and Canada equals that in protected areas. Environ. Sci. Policy, 101, 1-6.

Skroblin, A., Carboon, T., Bidu, G., Chapman, N., Miller, M., Taylor, K., Taylor, W., Game, E.T. \& Wintle, B.A. (2019). Including Indigenous knowledge in species distribution modelling for increased ecological insights. Conserv. Biol., cobi.13373.

Tilman, D., Clark, M., Williams, D.R., Kimmel, K., Polasky, S. \& Packer, C. (2017). Future threats to biodiversity and pathways to their prevention. Nature, 546, 73-81.

Toledo, V.M. (2013). Indigenous Peoples and Biodiversity. In: Encycl. Biodivers. Second Ed. pp. $269-278$ 
318 Global terrestrial Human Footprint maps for 1993 and 2009. Sci. Data, 3, 160067.

319 Venter, O., Sanderson, E.W., Magrach, A., Allan, J.R., Beher, J., Jones, K.R., Possingham,

320 H.P., Laurance, W.F., Wood, P., Fekete, B.M., Levy, M.A. \& Watson, J.E.M. (2016b).

321 Sixteen years of change in the global terrestrial human footprint and implications for

322 biodiversity conservation. Nat. Commun., 7, 12558.

323 Watson, J.E.M. \& Venter, O. (2017). A global plan for nature conservation. Nature.

324 Yates, F. (1934). Contingency tables involving small numbers and the $\chi 2$ test. J. R. Stat. Soc.

Suppl., 1, 217-235. 
bioRxiv preprint doi: https://doi.org/10.1101/2019.12.11.873695; this version posted December 14,2019 . The copyright holder for this preprint (which was not certified by peer review) is the author/funder, who has granted bioRxiv a license to display the preprint in perpetuity. It is made available under aCC-BY-NC-ND 4.0 International license.

328 Table 1. The number and percentage of species that have $\geq 10 \%$ (top number) and $>50 \%$

329 (bottom number) of their range overlapping with a specified land category.

330

\begin{tabular}{lcccc} 
Category & $\begin{array}{c}\text { All species } \\
(\mathbf{n = 2 0 , 3 2 8})\end{array}$ & $\begin{array}{c}\text { Amphibians } \\
(\mathbf{n = 4 , 9 9 3 )}\end{array}$ & $\begin{array}{c}\text { Mammals } \\
(\mathbf{n = 4 , 5 9 2})\end{array}$ & $\begin{array}{c}\text { Birds } \\
(\mathbf{n = 1 0 , 7 4 3 )}\end{array}$ \\
\hline $\begin{array}{l}\text { Total Indigenous } \\
\text { Peoples' lands }\end{array}$ & $\begin{array}{c}12,521(61.6) \\
3,314(16.3)\end{array}$ & $\begin{array}{c}2,249(45.0) \\
889(17.8)\end{array}$ & $\begin{array}{c}2,791(60.8) \\
807(17.6)\end{array}$ & $\begin{array}{c}7,481(69.6) \\
1618(15.1)\end{array}$ \\
& & & & \\
$\begin{array}{l}\text { Low-pressure } \\
\begin{array}{l}\text { Indigenous Peoples' } \\
\text { lands }\end{array}\end{array}$ & $3,989(19.6)$ & $754(15.1)$ & $875(19.1)$ & $2,360(22.0)$ \\
& $364(1.8)$ & $121(2.4)$ & $97(2.1)$ & $146(1.4)$ \\
\hline
\end{tabular}


bioRxiv preprint doi: https://doi.org/10.1101/2019.12.11.873695; this version posted December 14,2019 . The copyright holder for this preprint (which was not certified by peer review) is the author/funder, who has granted bioRxiv a license to display the preprint in perpetuity. It is made available under aCC-BY-NC-ND 4.0 International license.

333 Table 2. The number and percentage (in parentheses) of threatened species that have $\geq 10 \%$

334 (top number) and $>50 \%$ (bottom number) of their range overlapping with a specified land

\begin{tabular}{lcccc} 
Category & $\begin{array}{c}\text { All threatened } \\
\text { species } \\
(\mathbf{n = 4 , 5 2 3})\end{array}$ & $\begin{array}{c}\text { Threatened } \\
\text { amphibians } \\
(\mathbf{n = 2 , 0 4 6 )}\end{array}$ & $\begin{array}{c}\text { Threatened } \\
\text { mammals } \\
(\mathbf{n = 1 , 1 1 8})\end{array}$ & $\begin{array}{c}\text { Threatened } \\
\text { birds } \\
(\mathbf{n = 1 , 3 5 9})\end{array}$ \\
\hline $\begin{array}{l}\text { Total Indigenous } \\
\text { Peoples' lands }\end{array}$ & $\begin{array}{c}1,878(41.5) \\
840(18.6)\end{array}$ & $735(35.9)$ & $530(47.4)$ & $613(35.1)$ \\
& & & & $179(13.2)$ \\
Low-pressure & $418(9.2)$ & $155(7.6)$ & $137(12.3)$ & $126(9.3)$ \\
$\begin{array}{l}\text { Indigenous } \\
\text { Peoples' lands }\end{array}$ & $73(1.6)$ & $37(1.8)$ & $23(2.1)$ & $13(1.0)$ \\
\hline category. & & & &
\end{tabular}




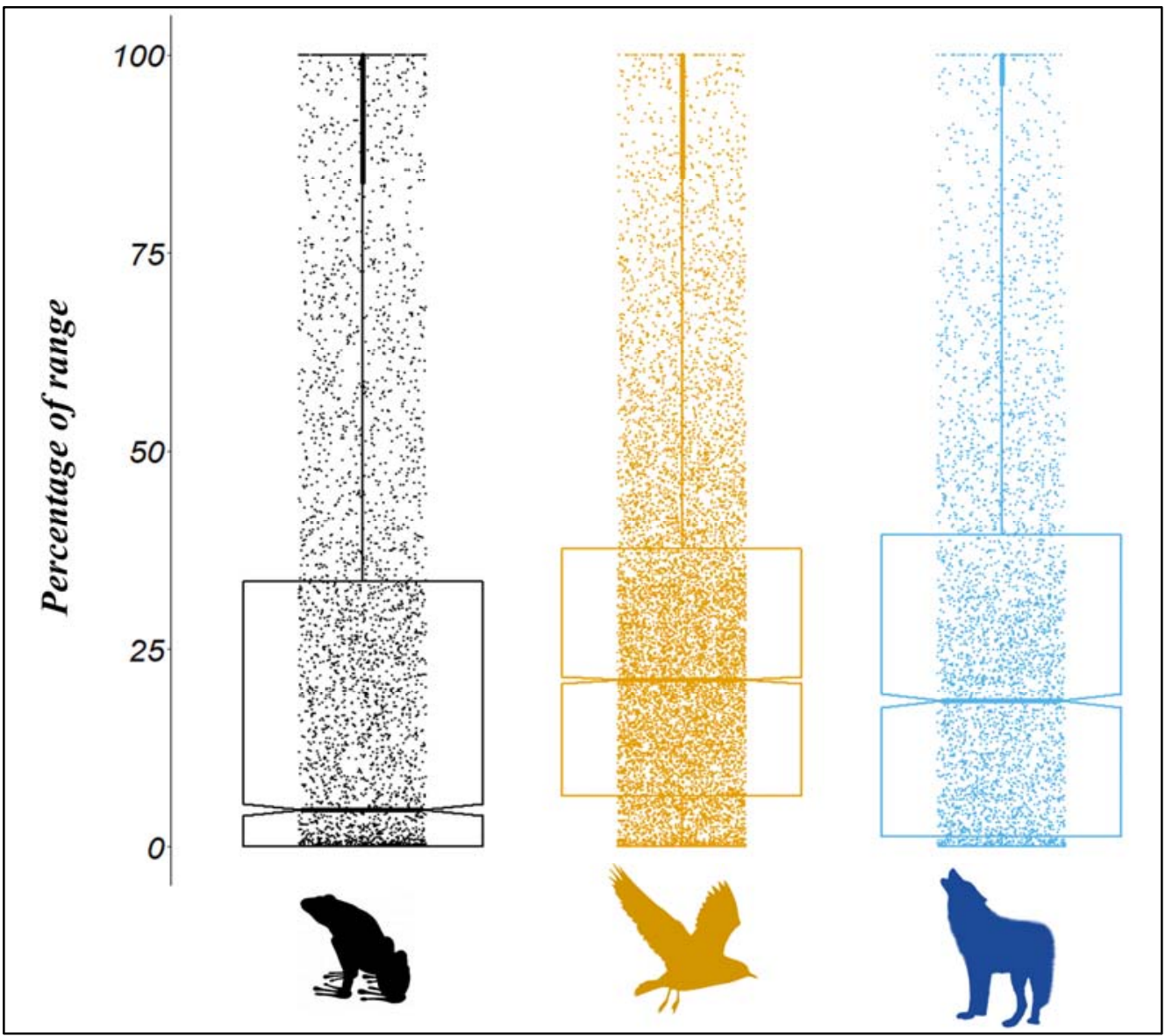

340 Figure 1. The percentage of species' ranges containing Indigenous Peoples' lands across

341 amphibians $(n=4,993)$, birds $(n=10,743)$, and mammals $(n=4,592)$ assessed by the IUCN

342 Red List. Each dot represents an individual species. The box plot denotes the lower quartile,

343 mean, and upper quartile for each species class. 


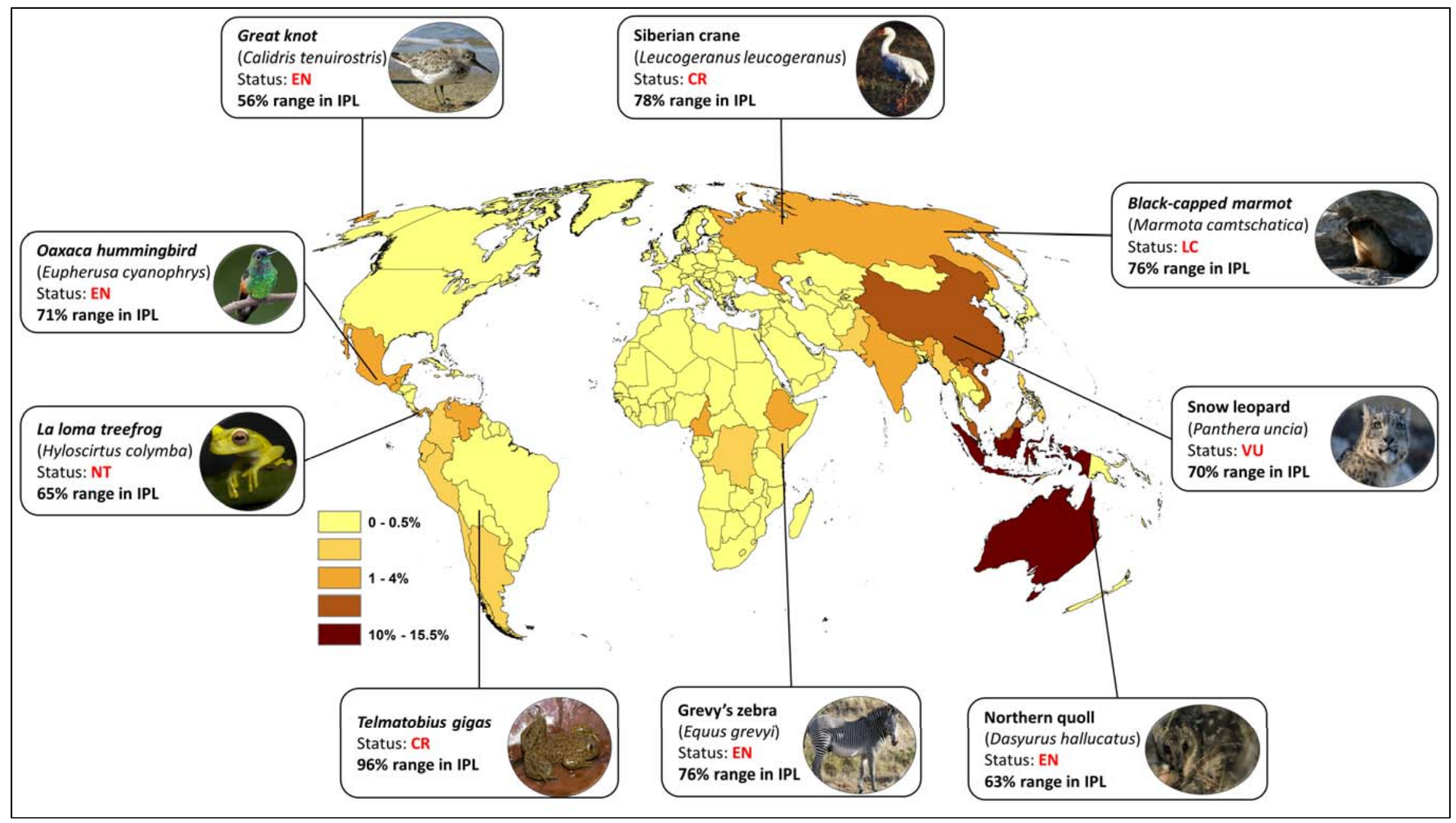

Figure 2. The proportion of species within each country that have $>50 \%$ of their range in Indigenous Peoples' lands (IPL) that are mapped

(Garnett et al. 2018), with a subset of exemplar species. 


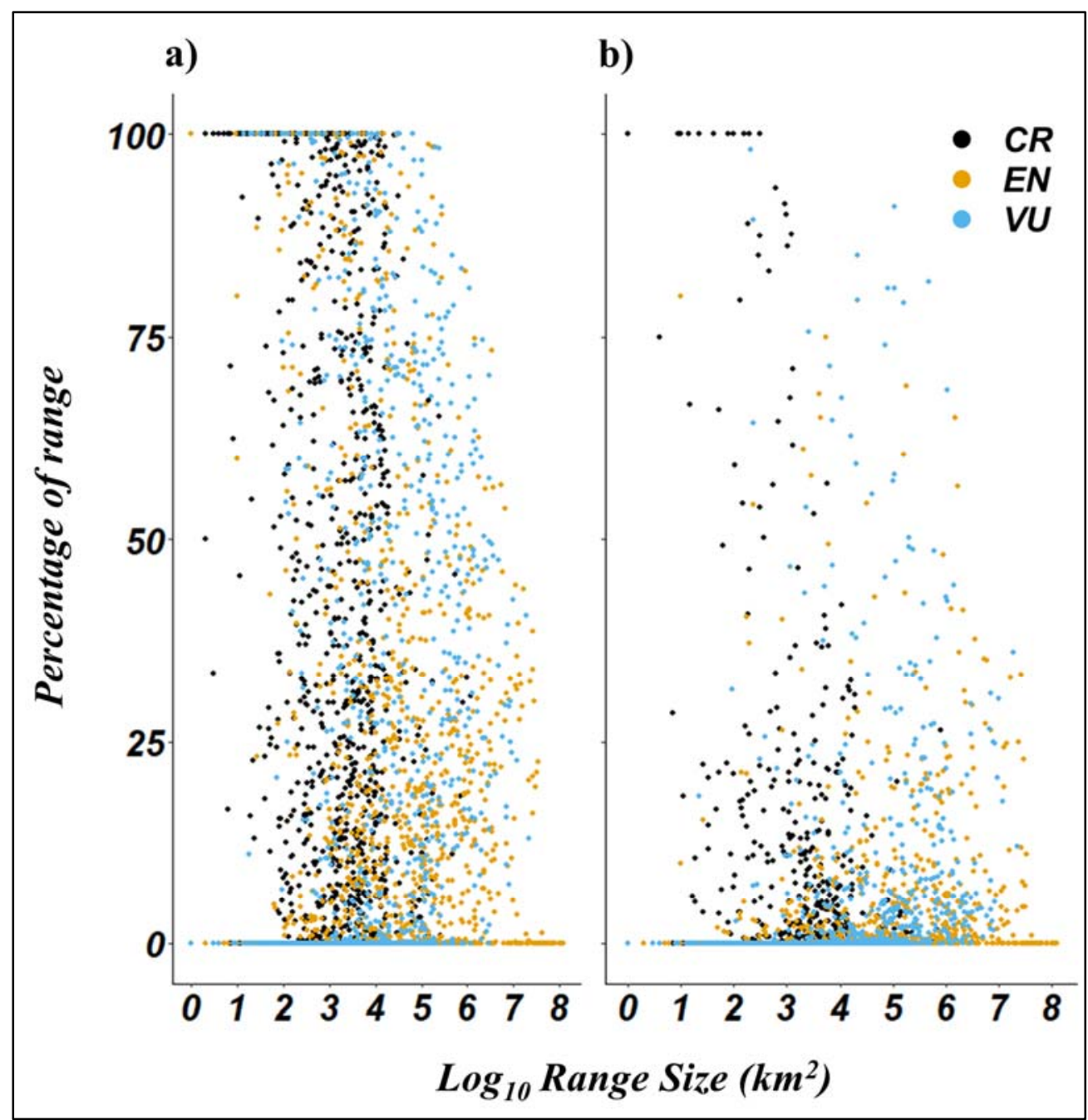

347 Figure 3. The proportion of threatened species ranges (a) within Indigenous Peoples' lands

348 and (b) Indigenous Peoples' lands that are mapped (Garnett et al. 2018) with low human

349 pressure broken down by levels of extinction risk as designated by the IUCN (CR = Critically

350 Endangered; $\mathrm{EN}=$ Endangered; $\mathrm{VU}=$ Vulnerable). 